Electronic Supplementary Material (ESI) for Energy \& Environmental Science.

This journal is () The Royal Society of Chemistry 2019

\title{
Crystalline Nickel, Cobalt, and Manganese Antimonates as Electrocatalysts for the
} Chlorine Evolution Reaction

\author{
Ivan A. Moreno-Hernandez ${ }^{1}$, Bruce S. Brunschwig ${ }^{2}$, Nathan S. Lewis ${ }^{1,2,3}$ \\ ${ }^{1}$ Division of Chemistry and Chemical Engineering, 127-72, California Institute of Technology, \\ Pasadena, CA 91125, USA \\ ${ }^{2}$ Beckman Institute Molecular Materials Research Center, California Institute of Technology, \\ Pasadena, CA 91125, USA \\ ${ }^{3}$ Kavli Nanoscience Institute, California Institute of Technology, Pasadena, CA 91125, USA \\ *Correspondence to: nslewis@caltech.edu
}




\section{Supplementary Information}

\section{Materials and Methods}

Chemicals

All chemicals were used as received, including antimony(III) chloride ( $\mathrm{SbCl}_{3}, \mathrm{Alfa}$ Aesar, ACS, 99.0\% min), tin(IV) chloride hydrate $\left(\mathrm{SnCl}_{4} \cdot \mathrm{xH}_{2} \mathrm{O}\right.$, Alfa Aesar, $98 \%$ ), sodium chloride ( $\mathrm{NaCl}$, Macron Chemicals, ACS grade), potassium iodide (KI, EMD Millipore, ACS grade), sodium thiosulfate pentahydrate $\left(\mathrm{Na}_{2} \mathrm{~S}_{2} \mathrm{O}_{3}\right.$, Alfa Aesar, ACS grade), 1.0 M hydrochloric acid (1.0 M HCl(aq), Fluka Analytical), multielement standard solution 1 for ICP (Sigma Aldrich, TraceCERT), sulfuric acid $\left(\mathrm{H}_{2} \mathrm{SO}_{4}(\mathrm{aq})\right.$, Fischer Scientific, TraceMetal grade, 93-98\%), sodium hydroxide ( $\mathrm{NaOH}$, Macron Chemicals, ACS grade), antimony standard for ICP (Sigma Aldrich, TraceCERT), potassium chloride (KCl, Macron Chemicals, ACS grade), and galliumindium eutectic (Alfa Aesar, 99.99\%). Deionized water with a resistivity of $18.2 \mathrm{M} \Omega$-cm was obtained from a Millipore deionized water system.

Sample Preparation

A previously described spray pyrolysis procedure was used to deposit conductive films of antimony-doped tin oxide (ATO). ${ }^{1,2}$ The process consisted of spraying a $0.24 \mathrm{M} \mathrm{SnCl}_{4}$ solution in ethanol doped with $3 \mathrm{~mol} \% \mathrm{SbCl}_{2}$ onto a quartz microscope slide heated at $550{ }^{\circ} \mathrm{C}$ on a hot plate. The thickness of the ATO film was adjusted by controlling the duration of the spray. ATO films with a sheet resistance of 5- $10 \Omega \mathrm{sq}^{-1}$, as determined from four-point probe measurements, were used for subsequent experiments.

Metallic films of $\mathrm{Ni}, \mathrm{Co}, \mathrm{Mn}, \mathrm{Sb}, \mathrm{NiSb}_{2}, \mathrm{CoSb}_{2}$, and $\mathrm{MnSb}_{2}$ were deposited onto the ATO substrates with an AJA Orion sputtering system. The ATO substrates were partially 
covered with Kapton tape to prevent complete coverage of the ATO with the catalyst films, to form a direct contact between the ATO and the working electrode wire. The metallic films were co-sputtered from four metallic targets in an Ar plasma: Antimony (ACI Alloys, 99.95\%), Nickel (ACI Alloys, 99.95\%), Cobalt (ACI Alloys, 99.95\%), and Manganese (ACI Alloys 99.95\%). The chamber pressure was $<10^{-7}$ Torr prior to the depositions. A chamber pressure of 5 mTorr was sustained during the depositions with an Ar flow rate of $20 \mathrm{sccm}$. The samples were not intentionally heated during the deposition process. The power applied to the metal targets was varied to obtain similar transition metal loadings and a stoichiometry close to 2:1 Sb:M in $\mathrm{MSb}_{\mathrm{x}}$ samples. The actual stoichiometry and loading of $\mathrm{Ni}, \mathrm{Co}, \mathrm{Mn}$, and $\mathrm{Sb}$ was determined by dissolving in $1.0 \mathrm{M} \mathrm{H}_{2} \mathrm{SO}_{4}(\mathrm{aq})$ films deposited on glass, and then using the concentration of the metals as determined by ICP-MS, the areas of the samples dissolved, and the amount of $\mathrm{H}_{2} \mathrm{SO}_{4}(\mathrm{aq})$ used during the dissolution to obtain the total loading.

After the metal films were deposited on ATO, the films were annealed in a muffle furnace (Thermolyne F48020-80) to form the crystalline oxides. ${ }^{2}$ Unless otherwise specified, the temperature was increased to $750{ }^{\circ} \mathrm{C}$ at a ramp rate of $10{ }^{\circ} \mathrm{C} \mathrm{min}-1$, was held at $750{ }^{\circ} \mathrm{C}$ for $6 \mathrm{~h}$, and then allowed to return to room temperature without active cooling. $\mathrm{RuTiO}_{\mathrm{x}}$ films with the same molar loading $(\sim 1.5 \mu \mathrm{mol} \mathrm{cm}-2)$ as the $\mathrm{MSb}_{2} \mathrm{O}_{\mathrm{x}}$ films were prepared by drop casting $4 \mu \mathrm{L}$ $\mathrm{cm}^{-2}$ of a $0.11 \mathrm{M} \mathrm{RuCl}_{3}$ and $0.26 \mathrm{M} \mathrm{TiCl}_{4}$ solution in ethanol onto ATO, followed by drying on a hot plate at $400{ }^{\circ} \mathrm{C} .{ }^{3}$ The $\mathrm{RuTiO}_{\mathrm{x}}$ was annealed at $500{ }^{\circ} \mathrm{C}$ for $1 \mathrm{~h}$ in a muffle furnace. ${ }^{3}$ The samples were cleaved into pieces that had exposed ATO regions, and In-Ga eutectic was scribed on the ATO. The electrode support consisted of a tinned $\mathrm{Cu}$ wire that was threaded through a glass tube. The $\mathrm{Cu}$ wire was coiled and bonded to the ATO substrate by use of Ag paint (SPI, Inc). The contact was allowed to dry for at least $2 \mathrm{~h}$ at room temperature or for $15 \mathrm{~min}$ at $85{ }^{\circ} \mathrm{C}$ 
in an oven. Hysol 9460 epoxy was used to insulate the $\mathrm{Cu}$, ATO, and In-Ga from the electrolyte and to define the geometric electrode area. The epoxy was allowed to cure for $>12 \mathrm{~h}$ at room temperature or for $2 \mathrm{~h}$ at $85^{\circ} \mathrm{C}$ in an oven. The electrode area and a calibration ruler was imaged with an optical scanner (Epson Perfection V360), and the electrode area was quantified with ImageJ software. Electrode areas were between 1 and $40 \mathrm{~mm}^{2}$ unless otherwise specified.

Materials Characterization

X-ray diffraction (XRD) data were collected with a Bruker D8 Discover instrument. The $\mathrm{Cu} \mathrm{K \alpha}(1.54 \AA) \mathrm{x}$-ray beam was generated with a tube current of $1000 \mu \mathrm{A}$ and a tube voltage of $50 \mathrm{kV}$, and was detected with a Vantec-500 2-dimensional detector. The incident beam was collimated with a $0.5 \mathrm{~mm}$ diameter mono-capillary collimator. A calibrated visible laser was used to align the sample with the $\mathrm{x}$-ray beam. XRD data were collected in coupled $\theta-2 \theta$ mode, with four scans collected every $20^{\circ}$ from a $2 \theta$ theta range of $20^{\circ}-80^{\circ}$. The x-ray radiation was collected for $1 \mathrm{~h}$ for each scan, corresponding to $4 \mathrm{~h}$ per sample. The 2-dimensional signal was integrated to obtain a 1-dimensional scan with an angular resolution of $0.01^{\circ} 2 \theta$. The x-ray diffraction peaks were analyzed using Bruker EVA software with reference patterns of $\mathrm{SnO}_{2}$ for the ATO substrate, in addition to reference patterns for monoclinic $\mathrm{Sb}_{2} \mathrm{O}_{4}$, orthorhombic $\mathrm{Sb}_{2} \mathrm{O}_{4}$, $\mathrm{NiSb}_{2} \mathrm{O}_{6}, \mathrm{CoSb}_{2} \mathrm{O}_{6}, \mathrm{MnSb}_{2} \mathrm{O}_{6}, \mathrm{RuO}_{2}$ and $\mathrm{TiO}_{2}$ obtained from the Crystallography Open Database or literature. ${ }^{4,5}$ Scanning-electron microscopy (SEM) images were collected using immersion mode with an accelerating voltage of $10 \mathrm{kV}$ on a Nova nanoSEM 450 (FEI) instrument.

X-ray Photoelectron Spectroscopy

X-ray photoelectron spectroscopy (XPS) scans were collected using a Kratos Axis NOVA (Kratos Analytical, Manchester, UK) at a background pressure of $<10^{-9}$ Torr. The x-ray 
source consisted of a monochromatic Al ka beam with an energy of $1486.6 \mathrm{eV}$. Survey scans were collected at $1.0 \mathrm{eV}$ resolution, and high-resolution scans were collected at $0.05 \mathrm{eV}$ resolution. The binding energy of the scans was corrected against the adventitious $\mathrm{C} 1 \mathrm{~s}$ peak with a constant offset to obtain an adventitious $\mathrm{C}$ 1s peak energy of $284.8 \mathrm{eV}$. The $\mathrm{M} 2 \mathrm{p}$ spectra of $\mathrm{Ni}$, Co, and Mn were fit using previously reported fitting parameters. ${ }^{6}$ The reported peak separations, FWHM ratios, and relative peak areas were used to fit the collected M 2p spectra. However, in most cases the peak shapes could not be fit adequately without shifting the peaks towards more positive binding energies. Since $\mathrm{MSb}_{2} \mathrm{O}_{\mathrm{x}}$ samples are chemically different than $\mathrm{MO}_{\mathrm{x}}$ or $\mathrm{M}(\mathrm{OH})_{2}$ samples, we tentatively assign the shifted peak shapes to $\mathrm{M}(\mathrm{II})$ in a $\mathrm{MSb}_{2} \mathrm{O}_{6}$ lattice. For example, while the peak position of $\mathrm{NiSb}_{2} \mathrm{O}_{\mathrm{x}}$ is similar to other $\mathrm{Ni}(\mathrm{II})$ species, the peak shape could not be adequately fit with Ni $2 p$ spectra of Ni oxide or hydroxide species. We introduced an addition peak shape that consisted of the $\mathrm{Ni}(\mathrm{OH})_{2}$ spectra shifted $1.0 \mathrm{eV}$ more positive. ${ }^{7}$ We tentatively assign this peak shape to $\mathrm{Ni}(\mathrm{II})$ in the $\mathrm{NiSb}_{2} \mathrm{O}_{6}$ lattice. The $\mathrm{XP}$ spectrum of $\mathrm{Sb}_{3} \mathrm{~d}_{3 / 2}$ was used to determine the oxidation state of the surface $\mathrm{Sb}$ on $\mathrm{MSb}_{2} \mathrm{O}_{\mathrm{x}}$ samples. Literature values of $\mathrm{Sb} 3 \mathrm{~d}_{3 / 2}$ peak binding energies for oxidation states of $3^{+}, 3^{+} / 5^{+}$, and $5^{+}$are $539.5 \mathrm{eV}, 540.1 \mathrm{eV}$, and 540.4 $\mathrm{eV}$ respectively, for a $\mathrm{C} 1$ s peak binding energy of $284.8 \mathrm{eV} .^{8}$

Electrochemical Testing

$\mathrm{NaCl}$ was used to make $4.0 \mathrm{M}$ aqueous solutions, and $1 \mathrm{M} \mathrm{HCl(aq)} \mathrm{was} \mathrm{used} \mathrm{to} \mathrm{adjust} \mathrm{the}$ $\mathrm{pH}$ to 2 as measured by a $\mathrm{pH}$ probe. A saturated calomel electrode (SCE) was calibrated with a normal hydrogen electrode (NHE). The NHE consisted of a platinum disk (CH Instruments) submerged in a $\mathrm{H}_{2}$ saturated 1.0 M sulfuric acid electrolyte, with $\mathrm{H}_{2}(\mathrm{~g})$ bubbled underneath the Pt disk to ensure saturation. The potential of the SCE was $0.244 \mathrm{~V}$ vs. NHE. Electrochemical measurements were collected in a two-compartment cell with the compartments separated using 
a Nafion N424 membrane. The cathode compartment was filled with $0.1 \mathrm{M} \mathrm{NaOH}(\mathrm{aq})$, and the anode compartment was filled with $4.0 \mathrm{M} \mathrm{NaCl}(\mathrm{aq})$ adjusted to $\mathrm{pH}=2$ with $\mathrm{HCl}(\mathrm{aq})$. After $48 \mathrm{~h}$ chronopotentiometry experiments, the $\mathrm{pH}$ of the electrolyte was usually $2.05-2.10$. The OER acidifies solutions, and the observations are consistent with the observed increase in $\mathrm{pH}$ arising from minor leakage of $\mathrm{NaOH}$ through the Nafion N424 membrane. The electrolyte was replaced after $48 \mathrm{~h}$ to prevent the $\mathrm{pH}$ from increasing. The working and reference electrodes were placed in the anode compartment, and the counter electrode was placed in the cathode compartment. The working, reference, and counter electrodes consisted of the sample, an SCE, and a carbon rod or $\mathrm{Ni}$ wire, respectively. The anode compartment was saturated with $\mathrm{Cl}_{2}(\mathrm{aq})$ by applying $10 \mathrm{~V}$ for at least $30 \mathrm{~min}$ between the counter electrode and a second working electrode that consisted of a graphite rod. The saturation of the electrolyte with $\mathrm{Cl}_{2}(\mathrm{aq})$ did not substantially affect the activity of the electrocatalysts or the $\mathrm{pH}$ of the electrolyte. However, this step was implemented to establish and maintain a well-defined potential based on the Nernst equation, which requires that $\mathrm{Cl}_{2}(\mathrm{aq})$ is present in the electrolyte. Cyclic voltammograms were collected at a scan rate of $10 \mathrm{mV} \mathrm{s}^{-1}$ unless otherwise specified. Electrochemical data were collected using a digital potentiostat (SP-200, Bio-Logic). The thermodynamic potential for chlorine evolution was calculated to be $1.331 \mathrm{~V}$ vs. $\mathrm{NHE}$ in $4.0 \mathrm{M} \mathrm{NaCl}(\mathrm{aq}){ }^{9}$

The roughness factor $(\mathrm{RF})$ of the TMAs was determined by comparing the electrochemically active surface area of bare ATO substrates and TMAs, as determined from impedance measurements. Impedance measurements were collected in $4.0 \mathrm{M} \mathrm{NaCl}(\mathrm{aq})$ adjusted to $\mathrm{pH}=2$ with the electrolyte additionally saturated with $\mathrm{Cl}_{2}(\mathrm{aq})$. Electrodes were held at 1.660 $\mathrm{V}$ vs. NHE for $15 \mathrm{~s}$ prior to impedance measurements, which were collected at the same potential with a frequency range of $20 \mathrm{~Hz}-20 \mathrm{kHz}$, with a sinusoidal wave amplitude of $10 \mathrm{mV}$. The 
impedance data were fit with a circuit model consisting of a resistor in series with a parallel component consisting of a constant phase element and another resistor. ${ }^{10}$ The capacitance was obtained by using a formula previously reported for the analysis of this circuit. ${ }^{10}$ The formula is shown below:

$C_{D L}=\left[Q_{0}\left(\frac{1}{R_{S}}+\frac{1}{R_{C T}}\right)(a-1)\right]^{\frac{1}{a}}$

Where $Q_{0}$ and $a$ are the parameters associated with the constant phase element, $R_{s}$ is the series resistance, $R_{c t}$ is the charge-transfer resistance, and $C_{D L}$ is the determined double-layer capacitance. The impedance data were fit using EC-Lab software by constraining all variables to positive values, and using the Randomize + Simplex method for at least 10,000 iterations. The fitting process was repeated at least four times to ensure that the best fit was obtained. Table S5 shows examples of impedance data collected for the electrocatalysts studied herein. ATO substrates prepared by a spray deposition method have previously been determined from atomic force microscopy measurements to have a $\mathrm{RF}=1.32 .^{2}$ The capacitance of ATO electrodes was determined with impedance measurements, and divided by the projected area of the electrodes to determine the geometric-area normalized capacitance. The geometric-area normalized capacitance of ATO was $14.4 \pm 1.6 \mu \mathrm{F} \mathrm{cm}^{-2}$, which corresponds to an electrochemical surface area normalized capacitance of $11 \pm 1 \mu \mathrm{F} \mathrm{cm}{ }_{\mathrm{ox}}{ }^{-2}$ after dividing by the $\mathrm{RF}=1.32$ of ATO. The roughness factor of the TMAs was determined by dividing the geometric-area normalized capacitance of the TMAs by the electrochemical surface area normalized capacitance of ATO $\left(11 \mu \mathrm{F} \mathrm{cm}{ }_{o x}^{-2}\right)$.

Inductively-coupled plasma mass spectrometry 
An Agilent 8000 Triple Quadrupole Inductively Coupled Plasma Mass Spectrometer (ICP-MS) system was used to determine the concentration of various ions in aqueous samples. Calibration solutions were prepared by diluting antimony and multielement standard solutions (Sigma Aldrich) with $18.2 \mathrm{M} \Omega \mathrm{cm}$ resistivity water. The concentration of various ions was determined from a linear fit of the counts per second of each standard solution versus the known concentration. The mass loading of the TMAs was determined by depositing the $\mathrm{MSb}_{2}(\mathrm{M}=\mathrm{Ni}$, $\mathrm{Co}, \mathrm{Mn}$ ) layers on glass slides that were then cut into $\sim 1 \mathrm{~cm}^{2}$ pieces. The projected area of the pieces was determined with a calibrated optical scanner and ImageJ software. The $\mathrm{MSb}_{2}$ layers were dissolved in $10 \mathrm{~mL}$ of $1.0 \mathrm{M} \mathrm{H}_{2} \mathrm{SO}_{4}(\mathrm{aq})$ for $>100 \mathrm{~h}$, and samples from these solutions were diluted with water and analyzed with ICP-MS. The loading of the catalyst layer was determined using the concentration of $\mathrm{M}$ and $\mathrm{Sb}$, the volume of $1.0 \mathrm{M} \mathrm{H}_{2} \mathrm{SO}_{4}(\mathrm{aq})$, and the projected area of the $\mathrm{MSb}_{2}$ layers. The dissolution of species from TMAs films under chlorine evolution conditions was determined by collecting $40 \mu \mathrm{L}$ samples of electrolyte from a cell operating at $100 \mathrm{~mA} \mathrm{~cm}^{-2}$ with an initial $5 \mathrm{~mL}$ volume of $4.0 \mathrm{M} \mathrm{NaCl}(\mathrm{aq}), \mathrm{pH}=2$ electrolyte in the anode compartment, and diluting these samples to $5 \mathrm{~mL}$ with $18.2 \mathrm{M} \Omega \mathrm{cm}$ resistivity water. For RuTiO $_{\mathrm{x}}$ samples, $1 \mathrm{~mL}$ of the electrolyte was collected from a $7 \mathrm{~mL}$ cell, and electrolyte was replenished after every sample was taken. The $1 \mathrm{~mL}$ samples were diluted to $10 \mathrm{~mL}$ with 18.2 $\mathrm{M} \Omega \mathrm{cm}$ resistivity water. The dissolution studies for $\mathrm{RuTiO}_{\mathrm{x}}$ could only be conducted for $\sim 20 \mathrm{~h}$, because the expected $\mathrm{Ru}$ dissolution product, $\mathrm{RuO}_{4}$, is a volatile compound that escapes the anode compartment in conjunction with the evolved $\mathrm{Cl}_{2}(\mathrm{~g})$, resulting in an underestimate of the Ru dissolution rate. ${ }^{11}$ ICP-MS measurements of Ru in the collected samples after $48 \mathrm{~h}$ of the initial measurements verified the volatility of the dissolved $\mathrm{Ru}$. The amount of $\mathrm{M}$ and $\mathrm{Sb}$ lost was determined from the concentration, volume of the cell, and electrode area. The amount of $\mathrm{M}$ 
and $\mathrm{Sb}$ removed from the cell after each sample was collected was taken into account when determining the amount of metals lost over time during chronopotentiometry measurements.

Chlorine Faradaic Efficiency and Oxygen Evolution Reaction Activity

The faradaic efficiency towards chlorine evolution was determined using an established iodometric titration technique. ${ }^{12-14}$ A two-compartment cell separated by a Nafion N424 membrane and with an $8 \mathrm{~mL}$ anode compartment was used for this study. The anode compartment was completely filled with $4.0 \mathrm{M} \mathrm{NaCl}(\mathrm{aq}), \mathrm{pH}=2$ electrolyte. Electrodes consisting of $\mathrm{RuTiO}_{\mathrm{x}}$ or TMAs were operated at $100 \mathrm{~mA} \mathrm{~cm}{ }^{-2}$ for 10 minutes. The electrolyte was transferred to a $25 \mathrm{~mL}$ Erlenmeyer flask containing $0.3 \mathrm{~g}$ of KI, and $0.2 \mathrm{~mL}$ of glacial acetic acid was added to the solution. The resulting yellow solution was titrated with $0.01 \mathrm{M}$ $\mathrm{NaS}_{2} \mathrm{O}_{3}$ (aq) using a $10 \mathrm{~mL}$ burette, and starch solution was added near the endpoint. This titration method requires 2 mol of $\mathrm{NaS}_{2} \mathrm{O}_{3}(\mathrm{aq})$ per mol of $\mathrm{Cl}_{2}(\mathrm{aq})$. The moles of $\mathrm{Cl}_{2}$ expected was calculated using the charge passed during the galvanostatic measurement, Faraday's constant (F, 96485.3389 $\left.\mathrm{C} \mathrm{mol}^{-1}\right)$, and the electrons required to obtain $\mathrm{Cl}_{2}\left(2\right.$ mol e- per $\left.\mathrm{mol} \mathrm{Cl}_{2}\right)$. The faradaic efficiency was determined by comparing the moles of $\mathrm{Cl}_{2}$ (aq) detected to the moles of $\mathrm{Cl}_{2}$ expected. Measurements were also collected for $4.0 \mathrm{M} \mathrm{NaCl}(\mathrm{aq}), \mathrm{pH}=2$ electrolyte that had not been used for electrochemical measurements as a blank. At least three measurements were collected per electrode. In these experiments, some minor nucleation of bubbles on the epoxy used to encapsulate the electrodes and the Teflon adapter used seal the electrochemical cell was observed. Since only dissolved species are detected by the iodometric technique, the faradaic efficiency measurements represent a lower limit on the Faradaic efficiency of the electrocatalysts studied herein. The generation of $\mathrm{Cl}_{2}(\mathrm{aq})$ was also verified with colorimetric measurements using $\mathrm{N}, \mathrm{N}$-diethyl-p-phenylenediamine. The high activity towards chlorine evolution relative to 
oxygen evolution was also verified by collecting cyclic voltammograms of $\mathrm{RuTiO}_{\mathrm{x}}$ and TMAs in $\mathrm{pH}=2 \mathrm{H}_{2} \mathrm{SO}_{4}(\mathrm{aq})$ electrolyte. 


\section{Supplementary Information Figures}

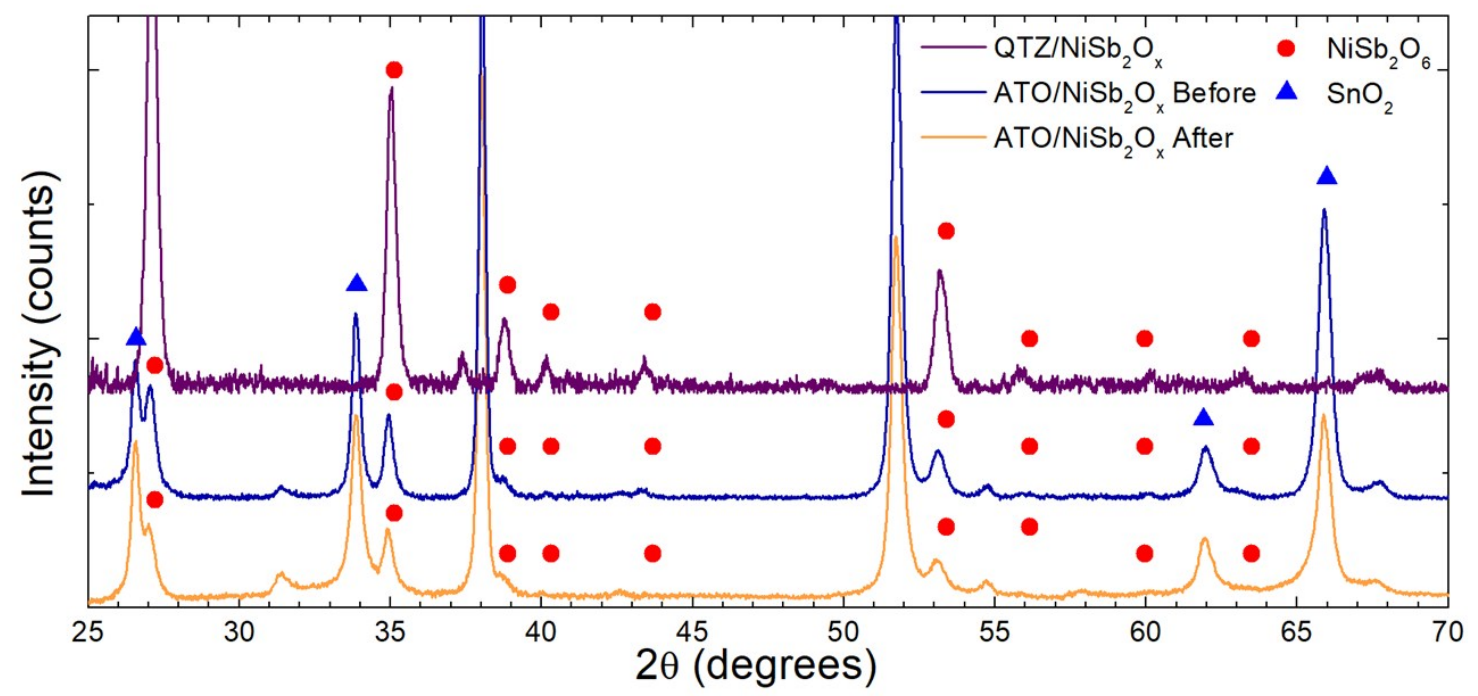

Figure S1. X-ray diffraction of as-synthesized $\mathrm{NiSb}_{2} \mathrm{O}_{\mathrm{x}}$ films on quartz and ATO, and $\mathrm{NiSb}_{2} \mathrm{O}_{\mathrm{x}}$ films after electrochemical operation in $4.0 \mathrm{M} \mathrm{NaCl}(\mathrm{aq}), \mathrm{pH}=2.0$ electrolyte at $100 \mathrm{~mA} \mathrm{~cm}{ }^{-2}$ for $65 \mathrm{~h}$.

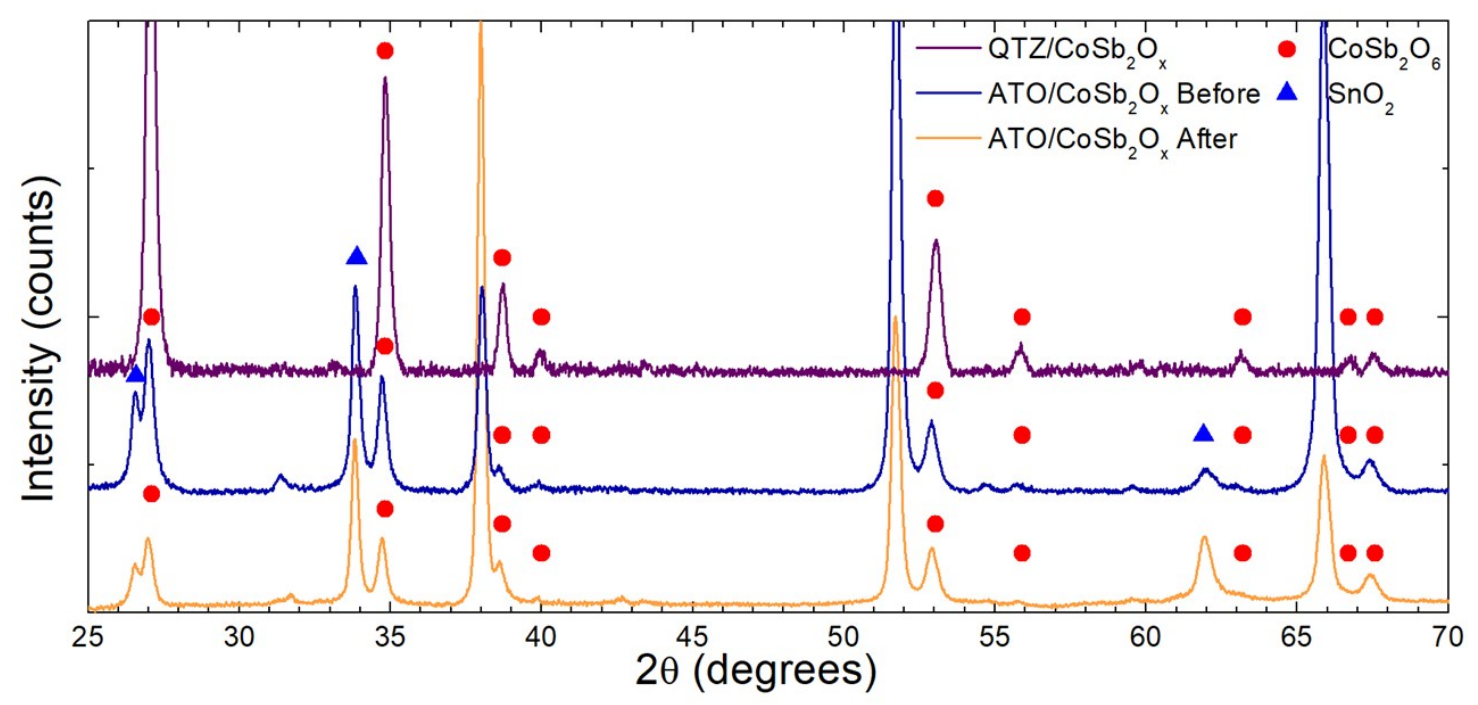


Figure S2. X-ray diffraction of as-synthesized $\mathrm{CoSb}_{2} \mathrm{O}_{\mathrm{x}}$ films on quartz and $\mathrm{ATO}$, and $\mathrm{CoSb}_{2} \mathrm{O}_{\mathrm{x}}$ films after electrochemical operation in $4.0 \mathrm{M} \mathrm{NaCl}(\mathrm{aq}), \mathrm{pH}=2.0$ electrolyte at $100 \mathrm{~mA} \mathrm{~cm}^{-2}$ for $90 \mathrm{~h}$.

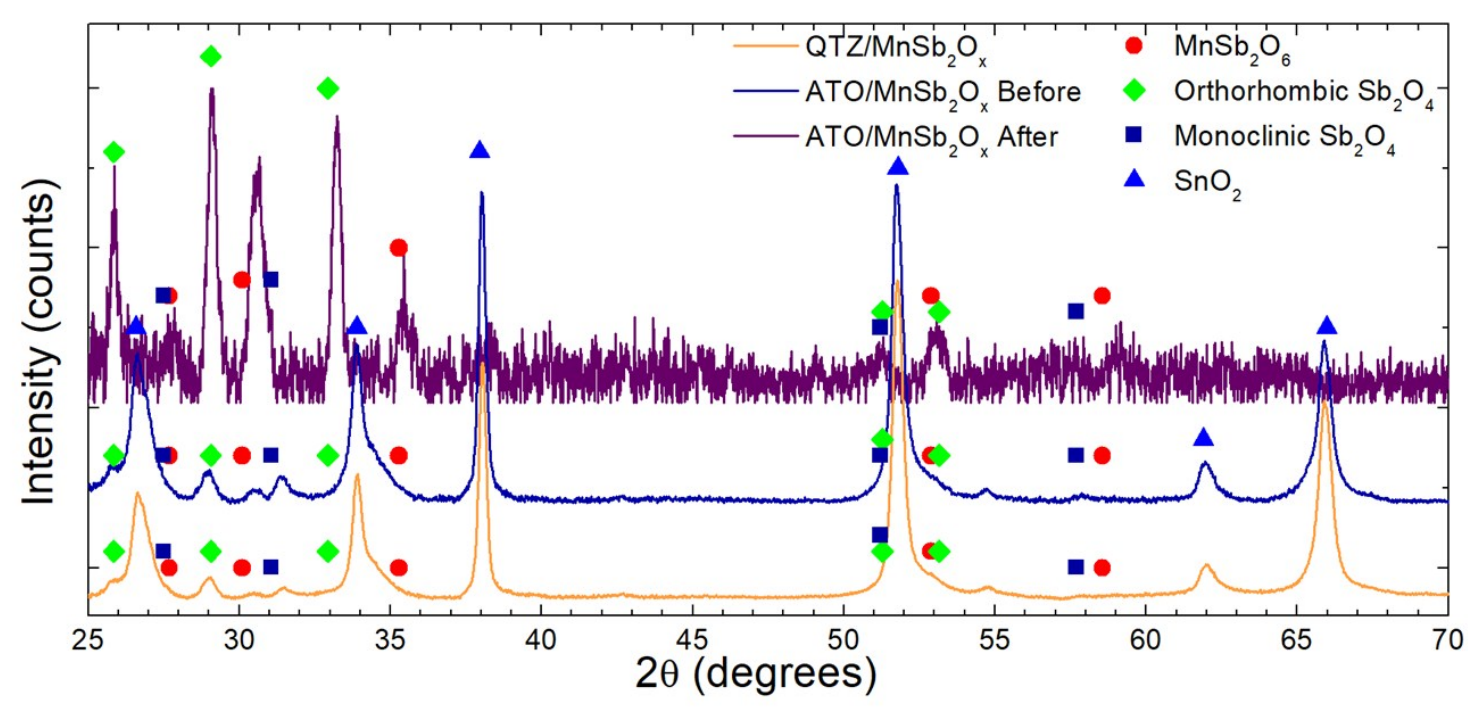

Figure S3. X-ray diffraction of as-synthesized $\mathrm{MnSb}_{2} \mathrm{O}_{\mathrm{x}}$ films on quartz and $\mathrm{ATO}$, and $\mathrm{MnSb}_{2} \mathrm{O}_{\mathrm{x}}$ films after electrochemical operation in $4.0 \mathrm{M} \mathrm{NaCl}(\mathrm{aq}), \mathrm{pH}=2.0$ electrolyte at 100 $\mathrm{mA} \mathrm{cm}{ }^{-2}$ for $90 \mathrm{~h}$.

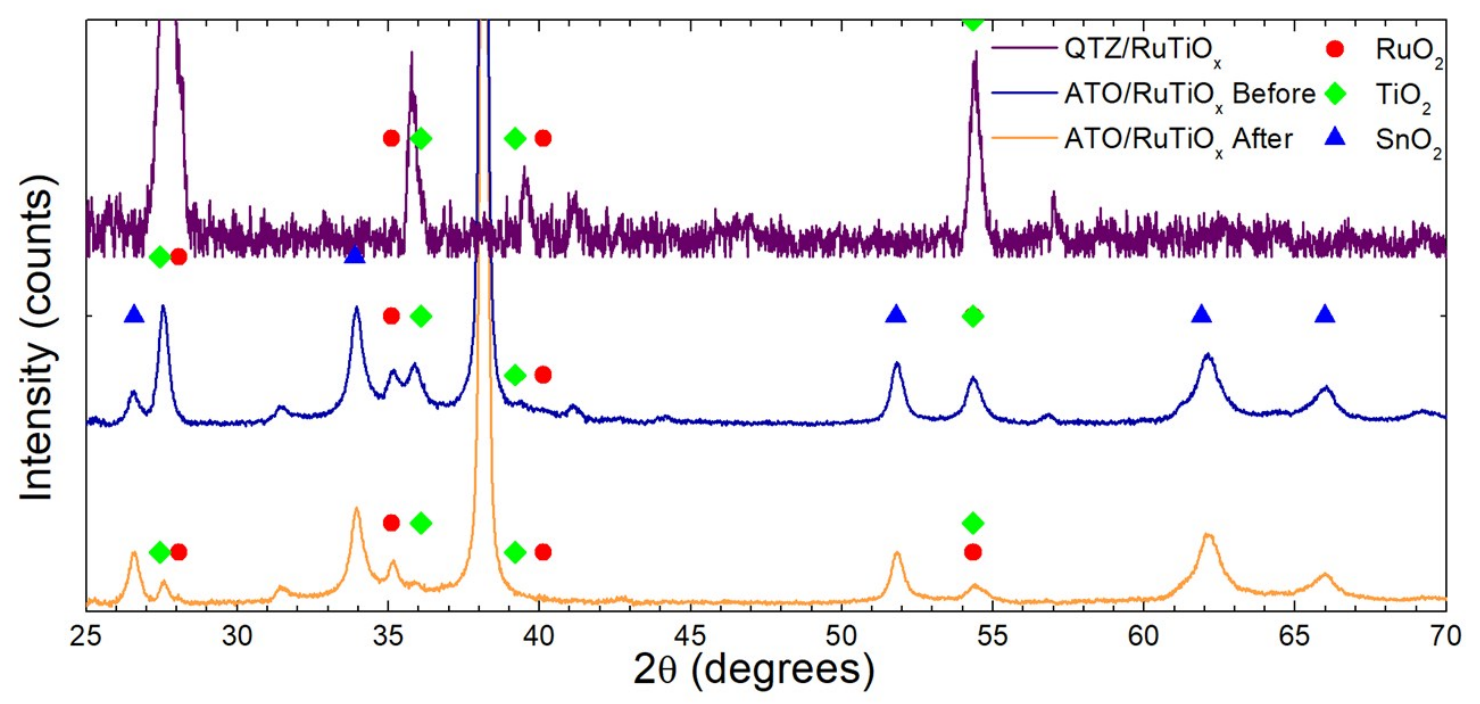


Figure S4. X-ray diffraction of as-synthesized $\mathrm{RuTiO}_{\mathrm{x}}$ films on $\mathrm{ATO}$, and $\mathrm{RuTiO}_{\mathrm{x}}$ films after electrochemical operation in $4.0 \mathrm{M} \mathrm{NaCl}(\mathrm{aq}), \mathrm{pH}=2.0$ electrolyte at $100 \mathrm{~mA} \mathrm{~cm}{ }^{-2}$ for $90 \mathrm{~h}$.
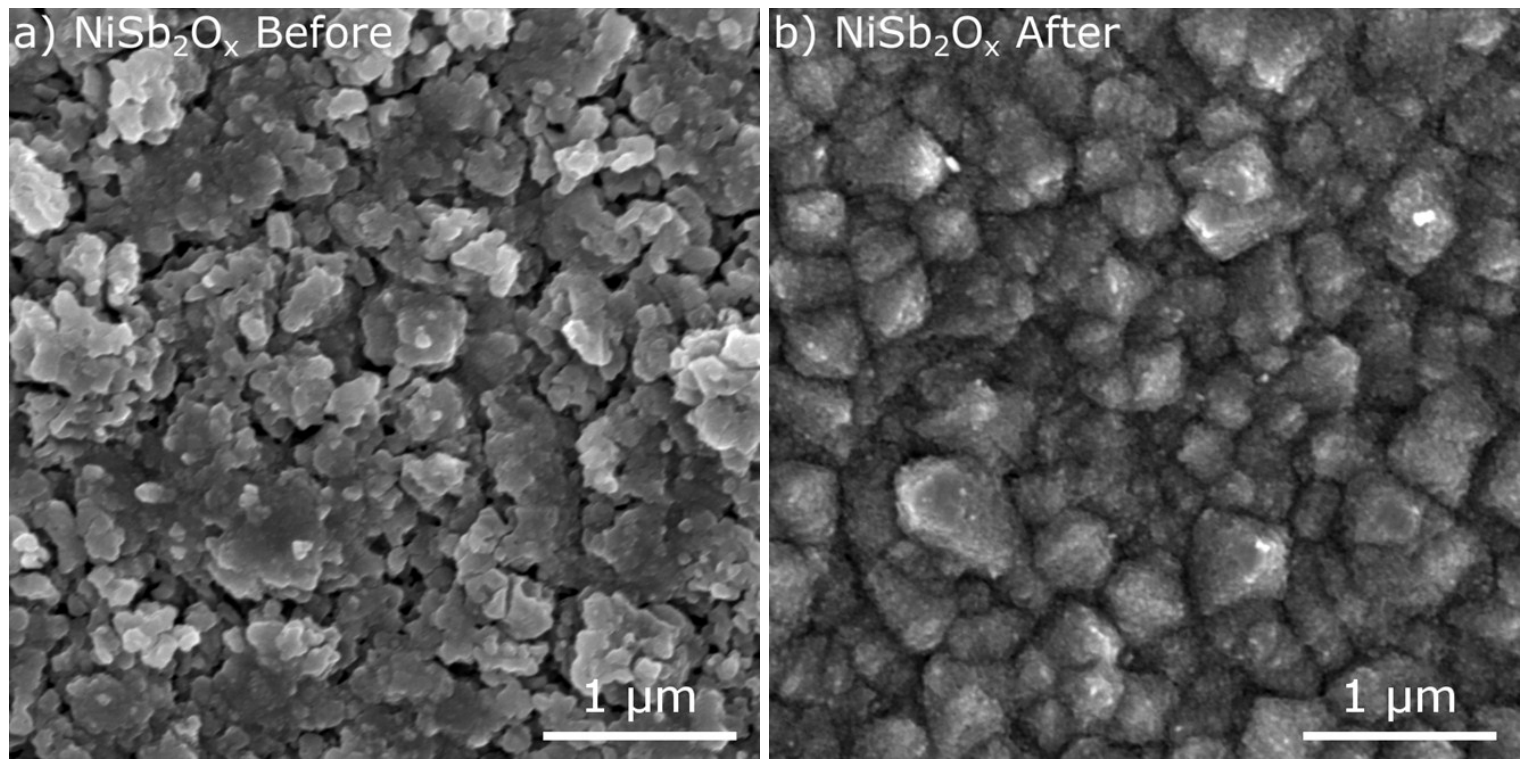

Figure S5. Scanning-electron microscope image of $\mathrm{NiSb}_{2} \mathrm{O}_{\mathrm{x}}$ : a) before operation, b) after $65 \mathrm{~h}$ at $100 \mathrm{~mA} \mathrm{~cm}^{-2}$ in $4.0 \mathrm{M} \mathrm{NaCl}(\mathrm{aq}), \mathrm{pH}=2.0$ electrolyte.
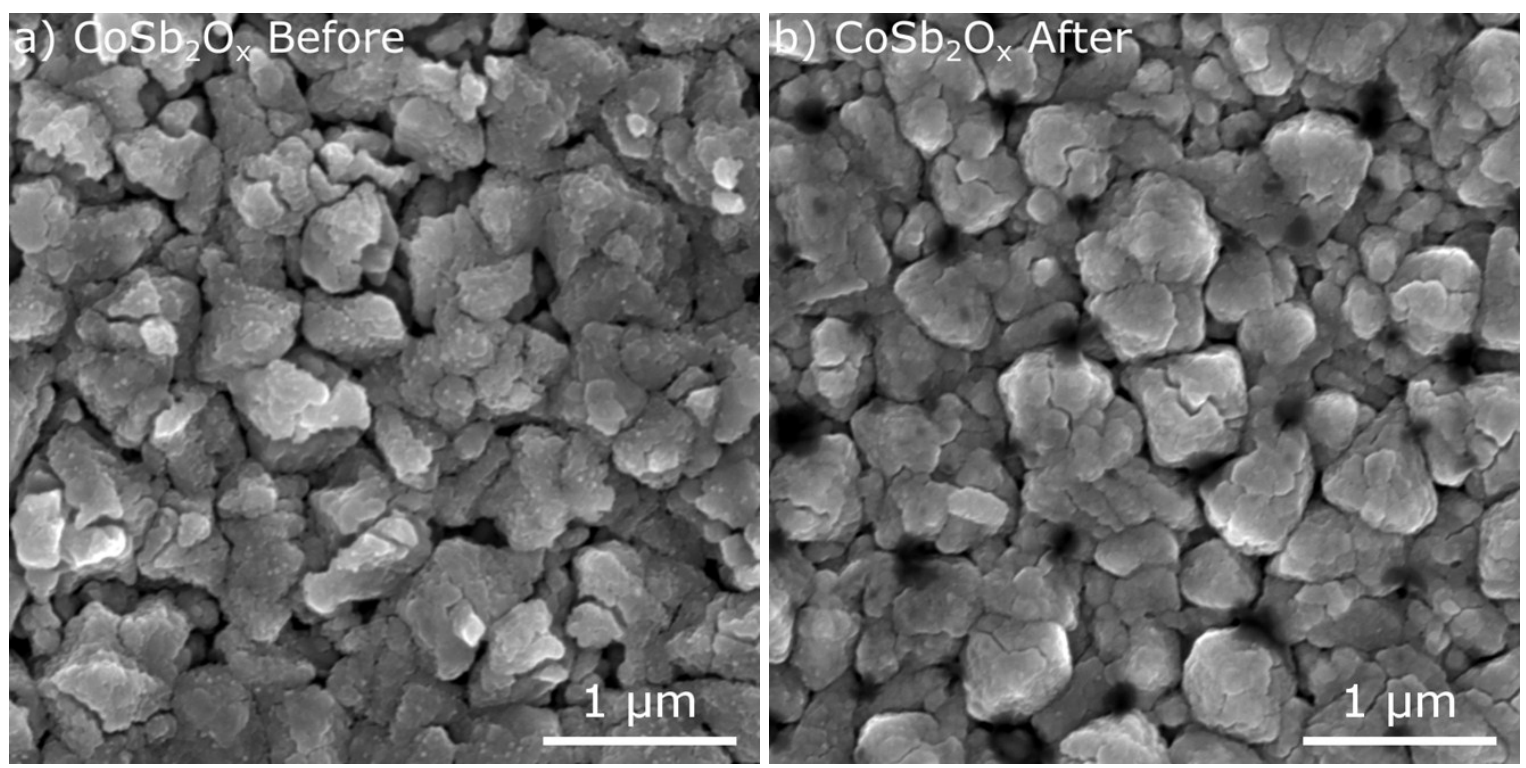
Figure S6. Scanning-electron microscope image of $\mathrm{CoSb}_{2} \mathrm{O}_{\mathrm{x}}$ : a) before operation, b) after $90 \mathrm{~h}$ at $100 \mathrm{~mA} \mathrm{~cm}^{-2}$ in $4.0 \mathrm{M} \mathrm{NaCl}(\mathrm{aq}), \mathrm{pH}=2.0$ electrolyte.
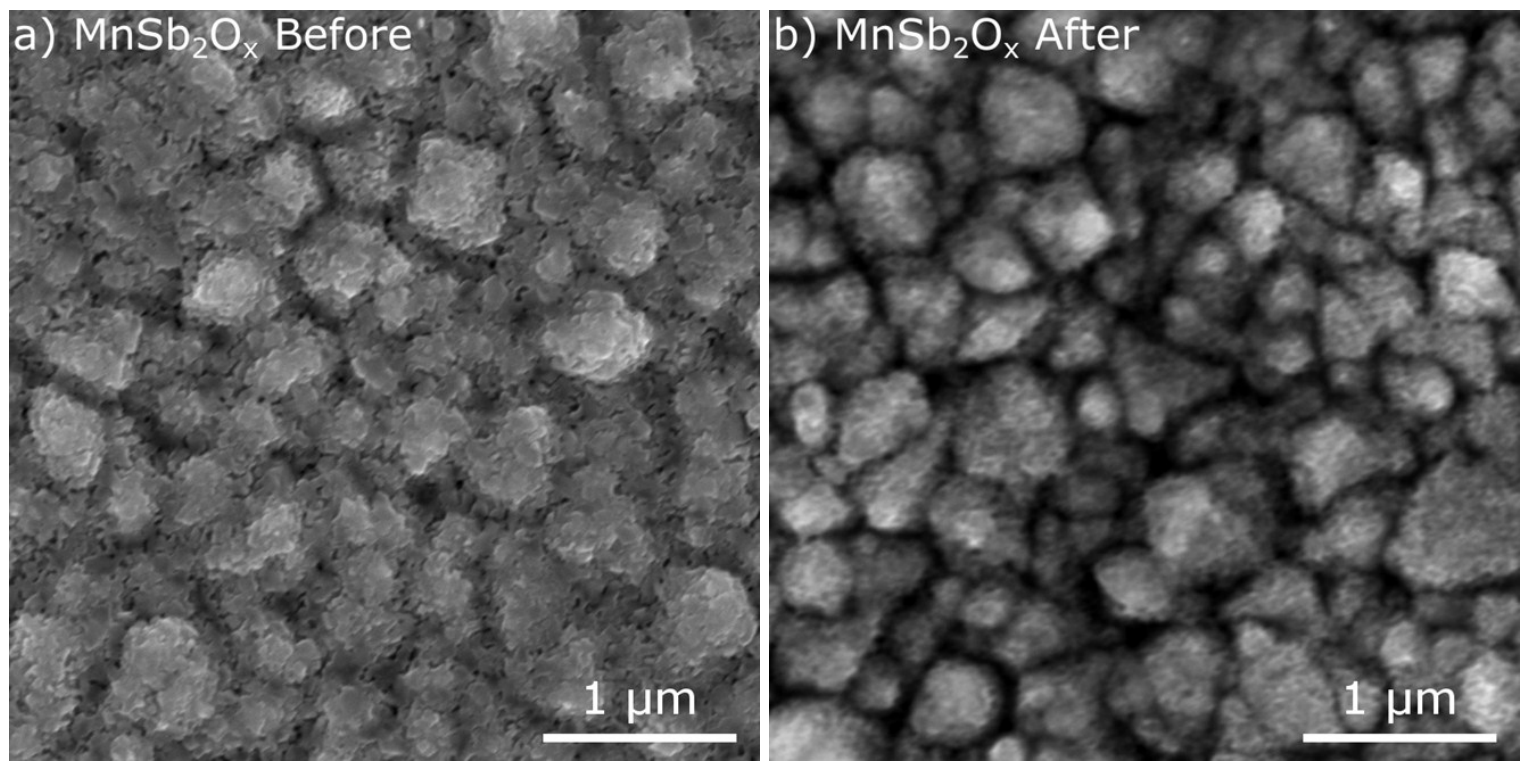

Figure S7. Scanning-electron microscope image of $\mathrm{MnSb}_{2} \mathrm{O}_{\mathrm{x}}$ : a) before operation, b) after $90 \mathrm{~h}$ at $100 \mathrm{~mA} \mathrm{~cm}^{-2}$ in $4.0 \mathrm{M} \mathrm{NaCl}(\mathrm{aq}), \mathrm{pH}=2.0$ electrolyte.
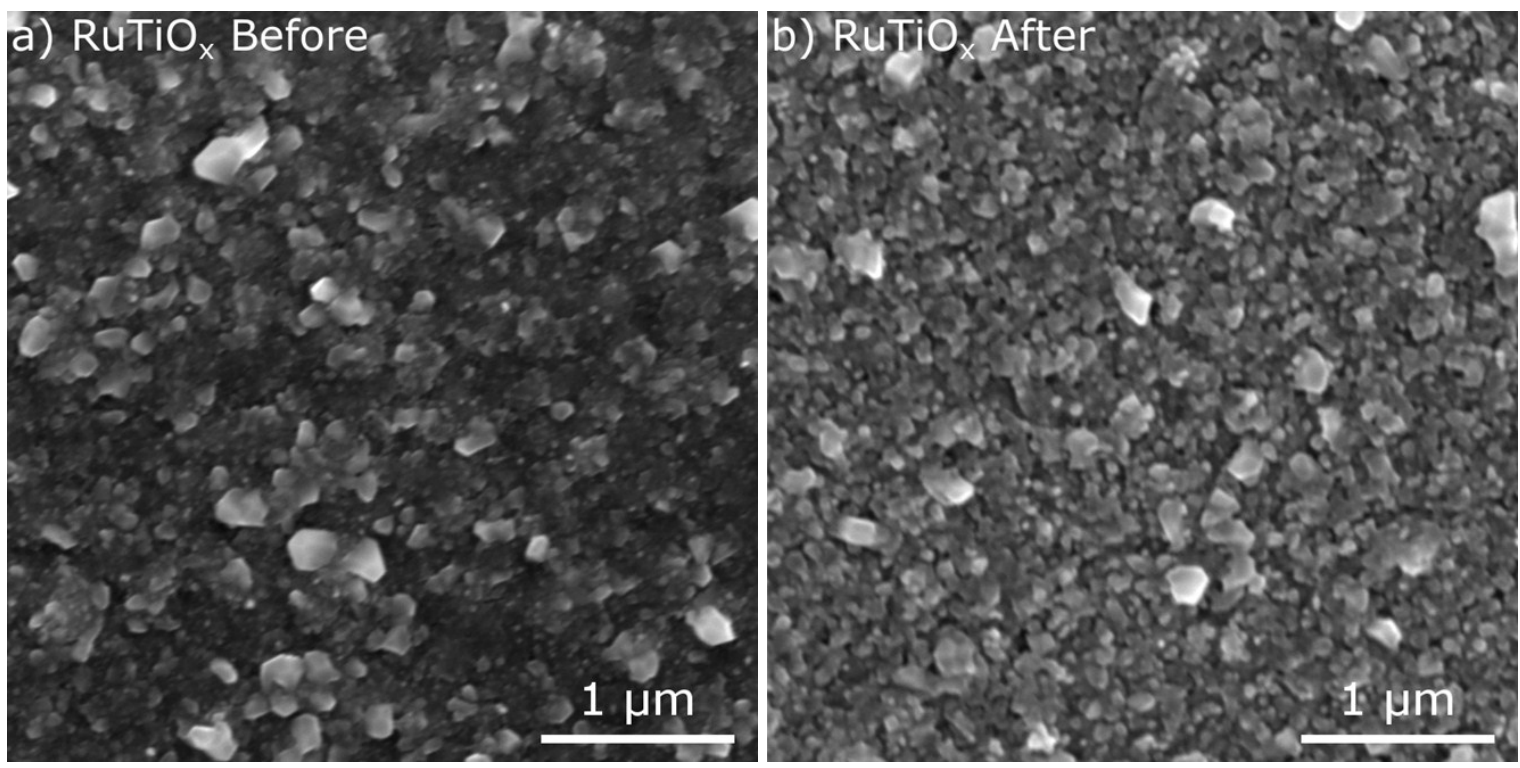
Figure S8. Scanning-electron microscope image of $\mathrm{RuTiO}_{\mathrm{x}}$ : a) before operation, b) after $90 \mathrm{~h}$ at $100 \mathrm{~mA} \mathrm{~cm}^{-2}$ in $4.0 \mathrm{M} \mathrm{NaCl}(\mathrm{aq}), \mathrm{pH}=2.0$ electrolyte.
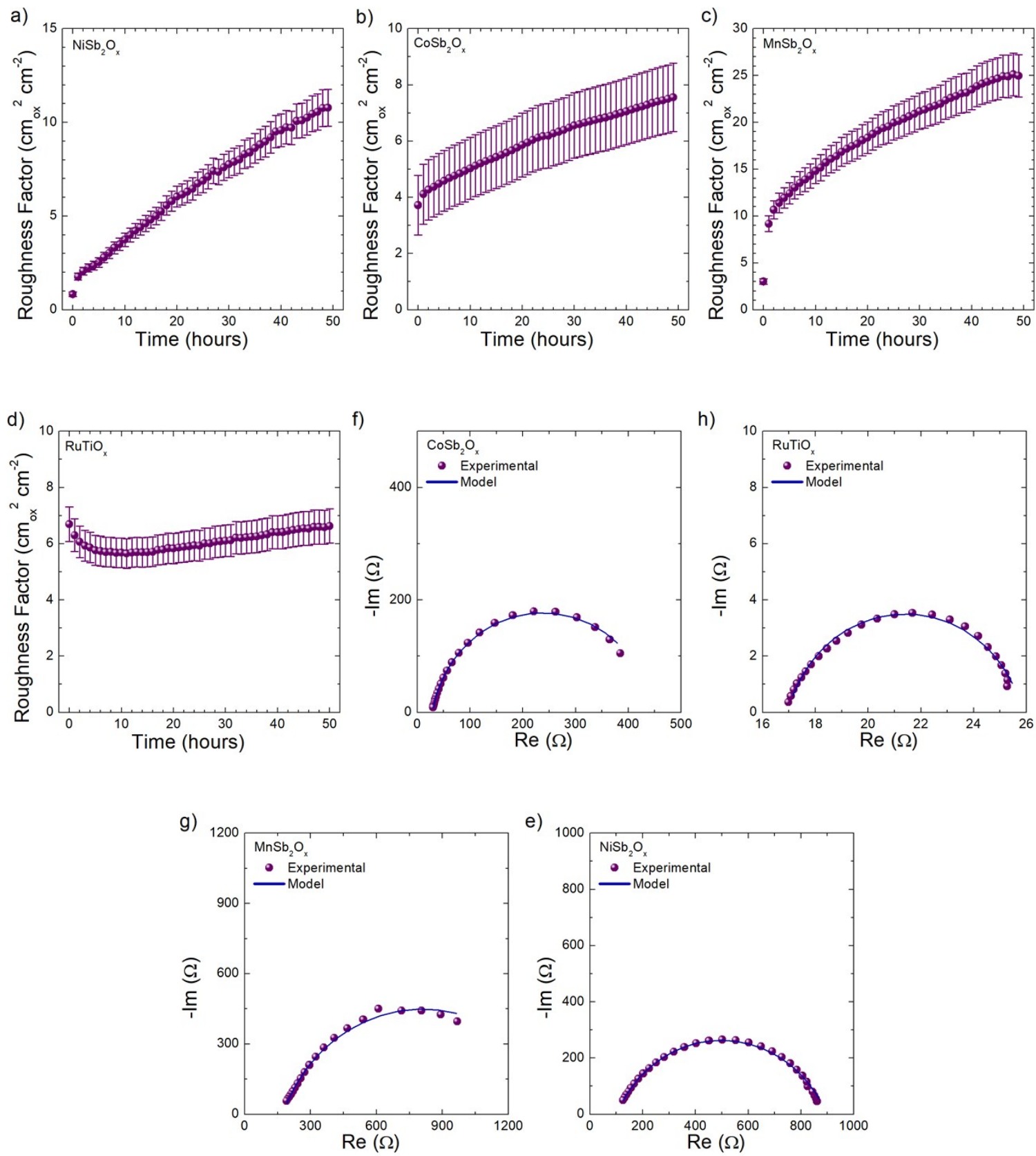

Figure S9. Roughness factor determined from impedance data collected at $1 \mathrm{~h}$ intervals between chronopotentiomery stability tests at $100 \mathrm{~mA} \mathrm{~cm}^{-2}$ for a) $\mathrm{NiSb}_{2} \mathrm{O}_{\mathrm{x}}$, b) $\left.\mathrm{CoSb}_{2} \mathrm{O}_{\mathrm{x}}, \mathrm{c}\right) \mathrm{MnSb}_{2} \mathrm{O}_{\mathrm{x}}$, and 
d) $\mathrm{RuTiO}_{\mathrm{x}}$. Comparison between initial impedance data and impedance model fit for e) $\mathrm{NiSb}_{2} \mathrm{O}_{\mathrm{x}}$, f) $\left.\mathrm{CoSb}_{2} \mathrm{O}_{\mathrm{x}}, \mathrm{g}\right) \mathrm{MnSb}_{2} \mathrm{O}_{\mathrm{x}}$, and h) $\mathrm{RuTiO}_{\mathrm{x}}$.

a)

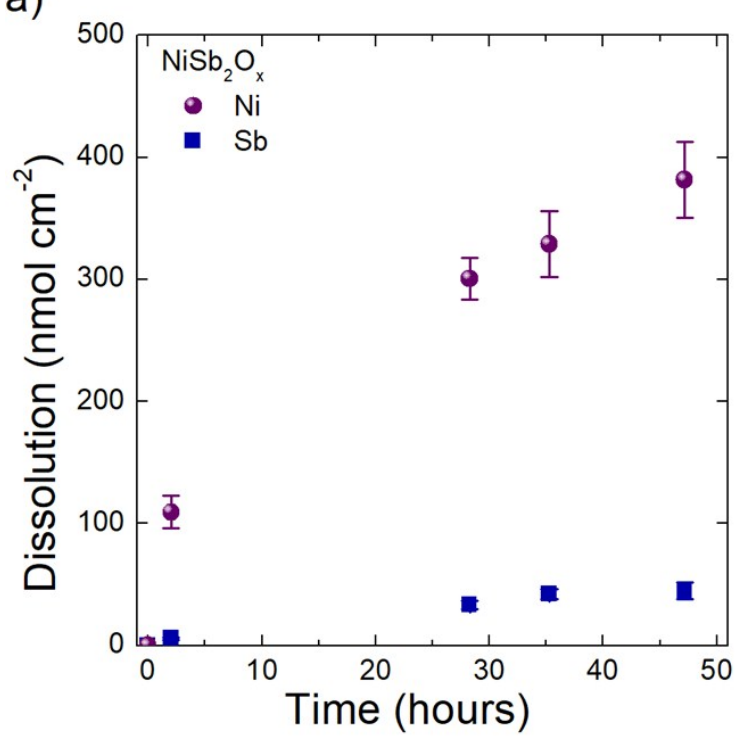

b)

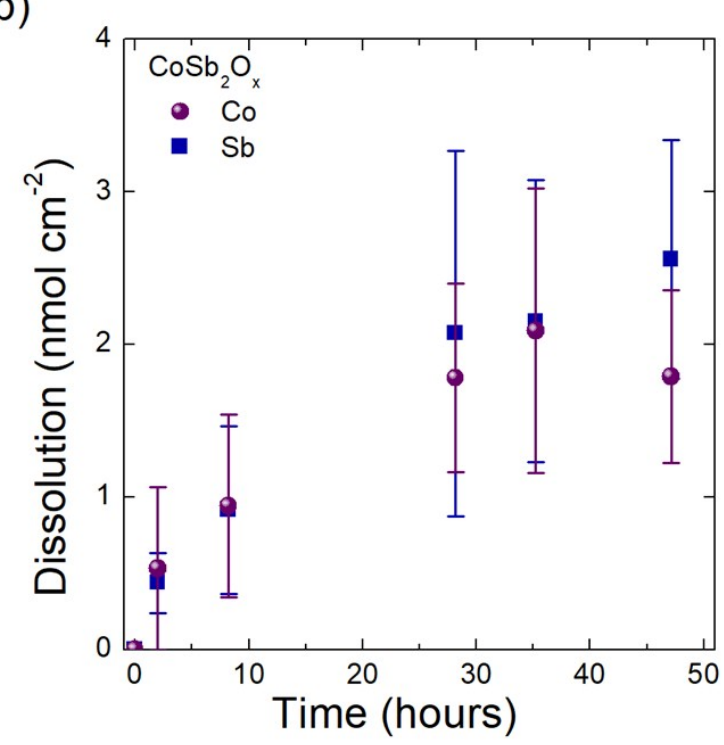

d)

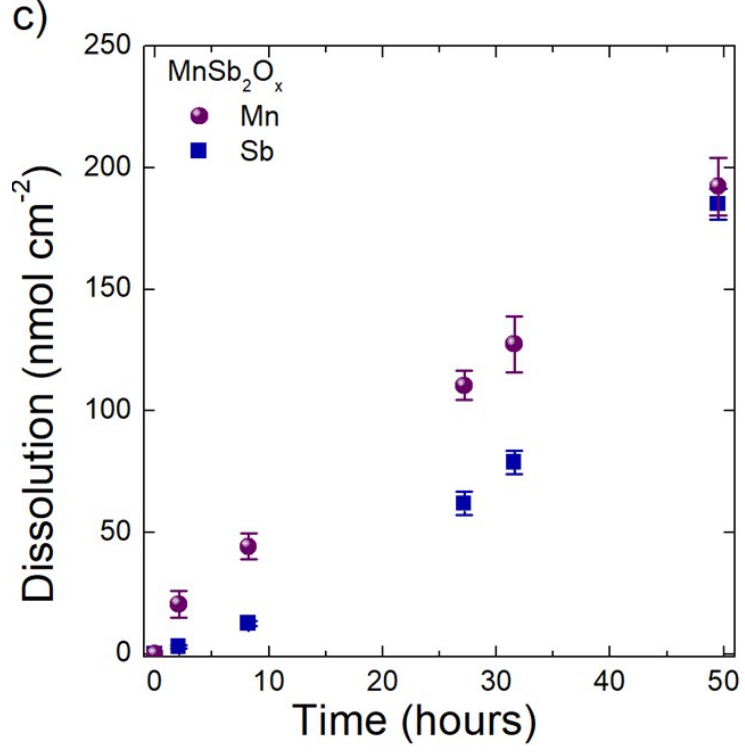

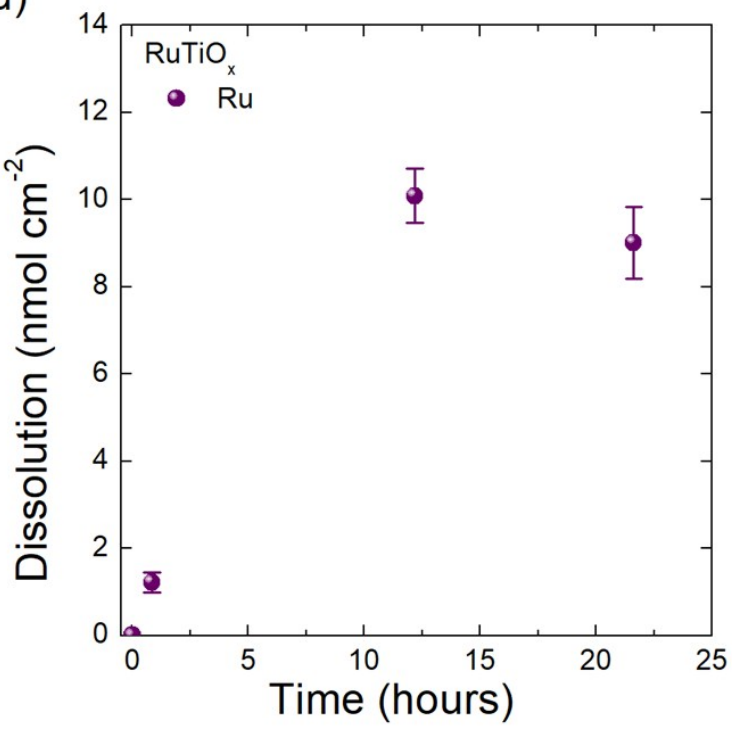

Figure S10. Amount of elements dissolved from $\mathrm{MSb}_{2} \mathrm{O}_{\mathrm{x}}$ and $\mathrm{RuTiO}_{\mathrm{x}}$ electrodes operated at 100 $\mathrm{mA} \mathrm{cm}{ }^{-2}$ in $4.0 \mathrm{M} \mathrm{NaCl}, \mathrm{pH}=2.0$ electrolyte: a) $\mathrm{NiSb}_{2} \mathrm{O}_{\mathrm{x}}$, b) $\mathrm{CoSb}_{2} \mathrm{O}_{\mathrm{x}}$, c) $\mathrm{MnSb}_{2} \mathrm{O}_{\mathrm{x}}$, d) $\mathrm{RuTiO}_{\mathrm{x}}$. 
a)

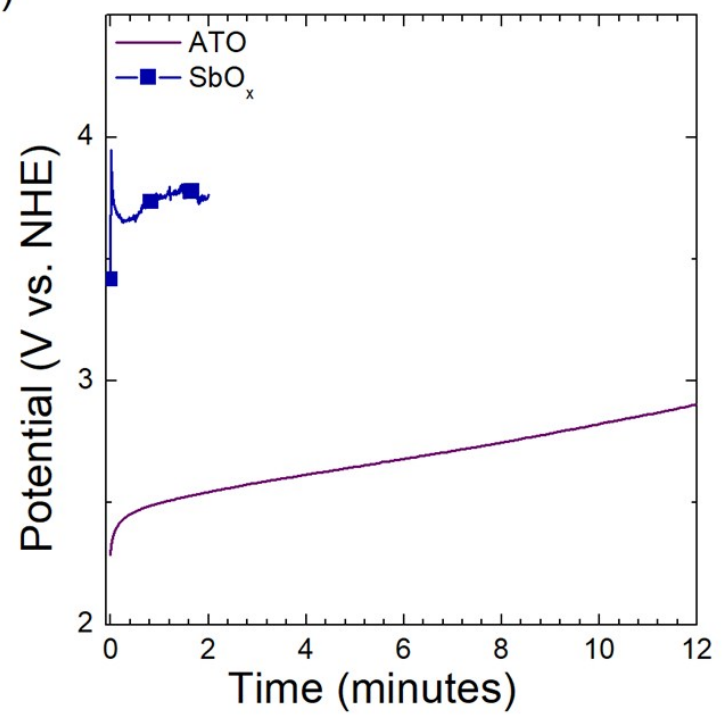

b)

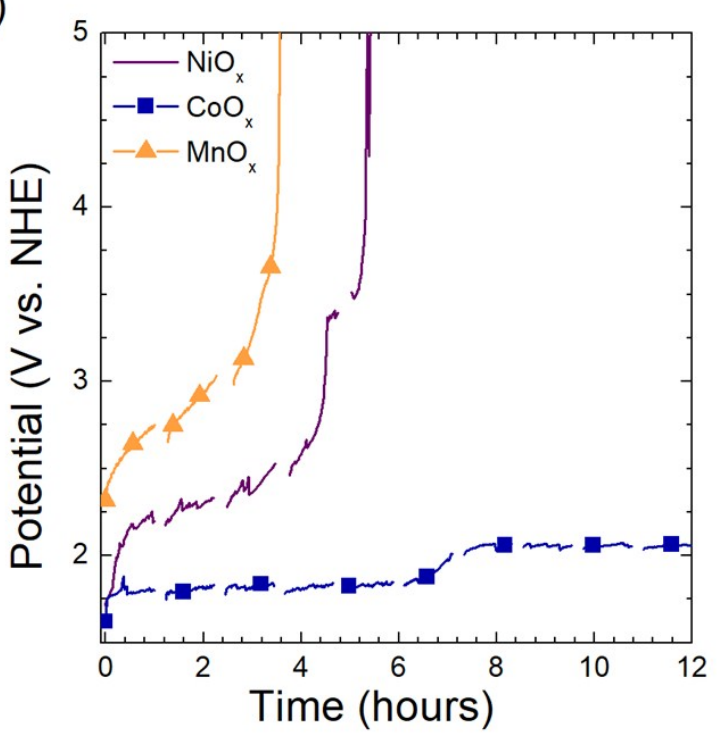

Figure S11. a) Chronopotentiometry of ATO and $\mathrm{SbO}_{\mathrm{x}}$ at $100 \mathrm{~mA} \mathrm{~cm}^{-2}$.b) Chronopotentiometry of $\mathrm{NiO}_{\mathrm{x}}, \mathrm{CoO}_{\mathrm{x}}$, and $\mathrm{MnO}_{\mathrm{x}}$ at $100 \mathrm{~mA} \mathrm{~cm}{ }^{-2}$. 

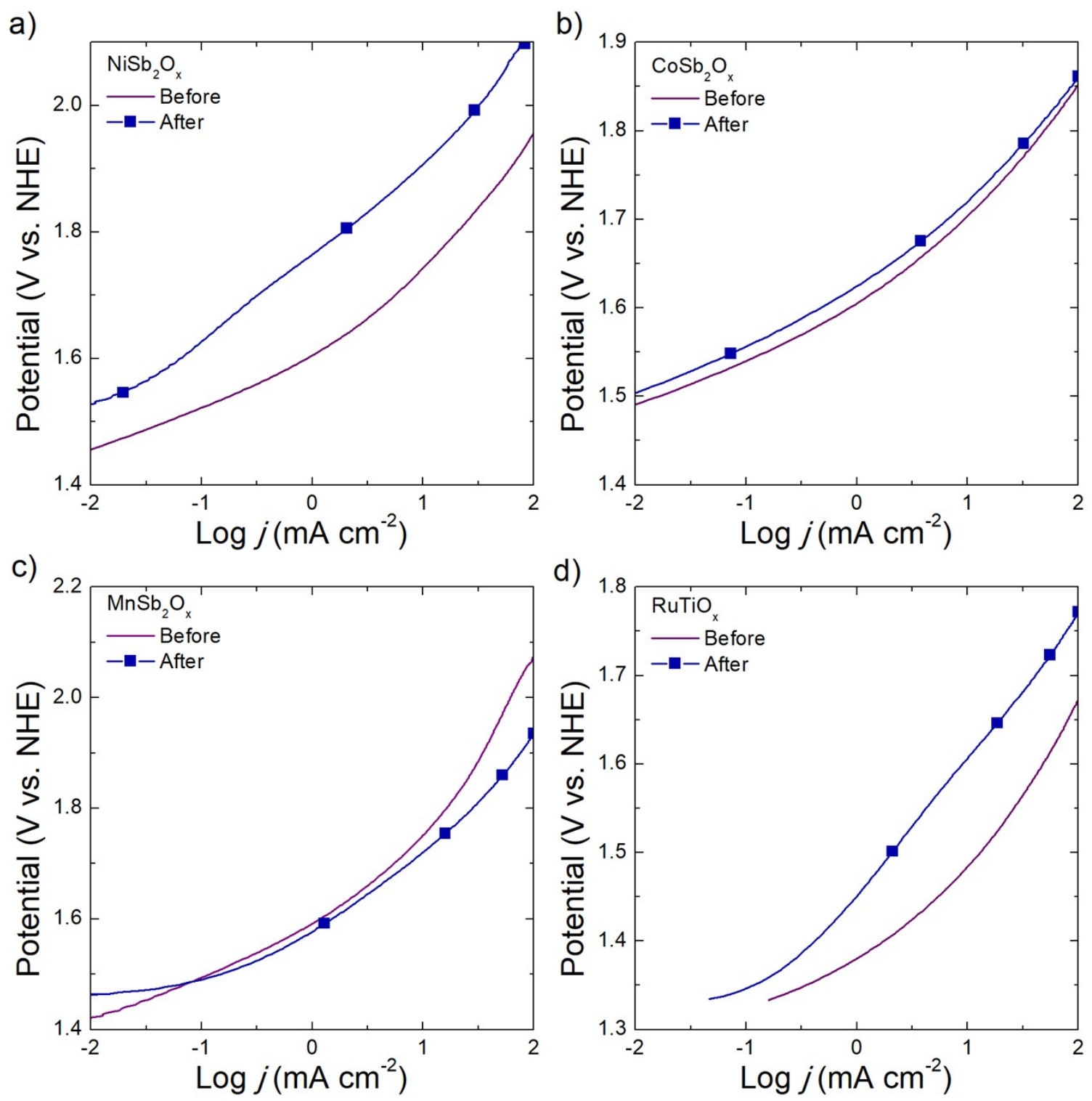

Figure S12. Tafel plots from $10^{-2}$ to $10^{2} \mathrm{~mA} \mathrm{~cm}^{-2}$ before and after $50 \mathrm{~h}$ at $100 \mathrm{~mA} \mathrm{~cm}-2$ for a) $\mathrm{NiSb}_{2} \mathrm{O}_{\mathrm{x}}$, b) $\left.\mathrm{CoSb}_{2} \mathrm{O}_{\mathrm{x}}, \mathrm{c}\right) \mathrm{MnSb}_{2} \mathrm{O}_{\mathrm{x}}$, d) $\mathrm{RuTiO}_{\mathrm{x}}$. The current-voltage data was collected from cyclic voltammograms. 

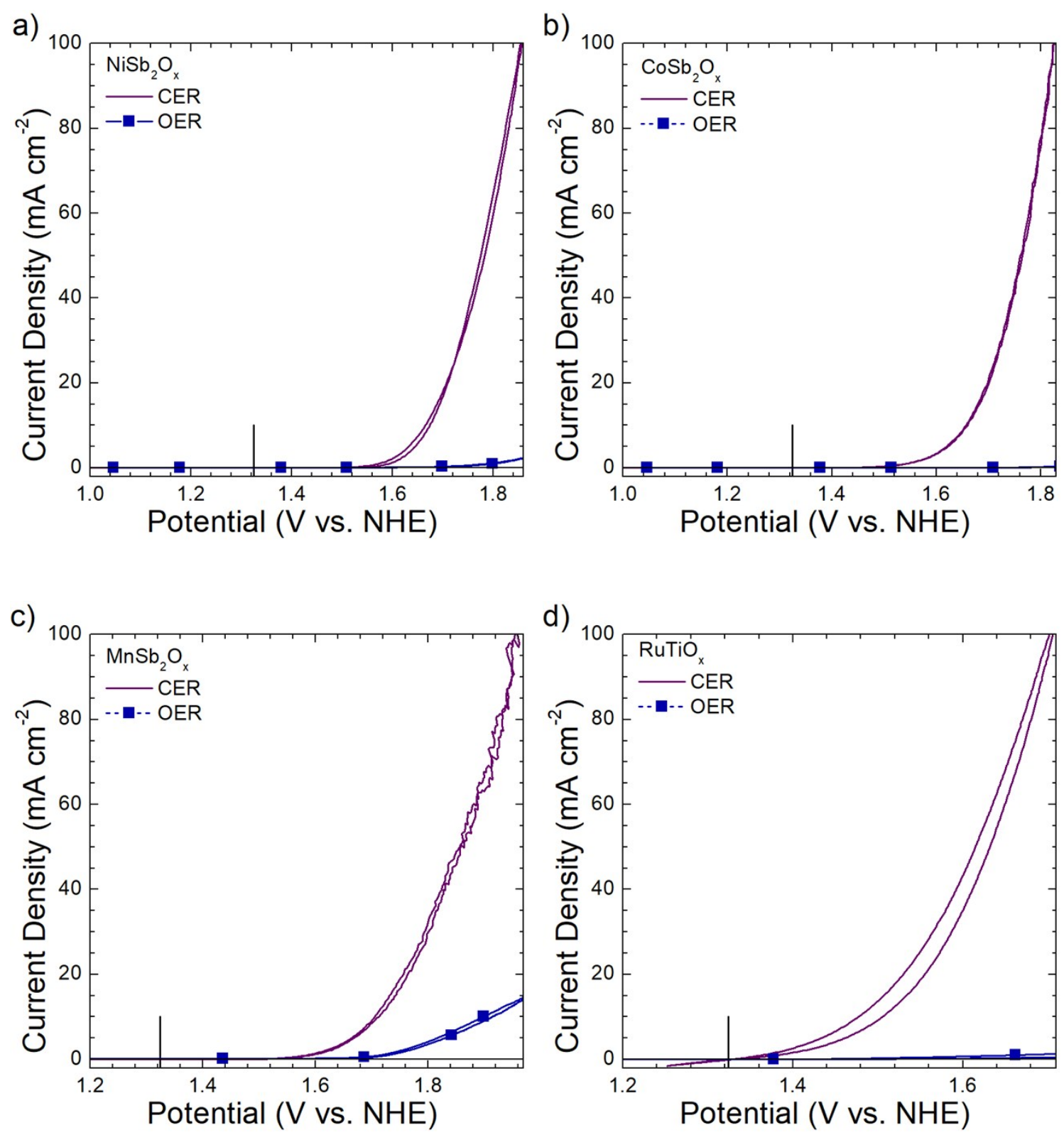

Figure S13. Cyclic voltammograms collected under chlorine evolution conditions $[4.0 \mathrm{M}$ $\mathrm{NaCl}(\mathrm{aq}), \mathrm{pH}=2.0]$ and oxygen evolution conditions $\left[\mathrm{pH}=2.0 \mathrm{H}_{2} \mathrm{SO}_{4}(\mathrm{aq})\right]$ for a) $\mathrm{NiSb}_{2} \mathrm{O}_{\mathrm{x}}, \mathrm{b}$ ) $\left.\mathrm{CoSb}_{2} \mathrm{O}_{\mathrm{x}}, \mathrm{c}\right) \mathrm{MnSb}_{2} \mathrm{O}_{\mathrm{x}}$, and d) $\mathrm{RuTiO}_{\mathrm{x}}$. 
a)

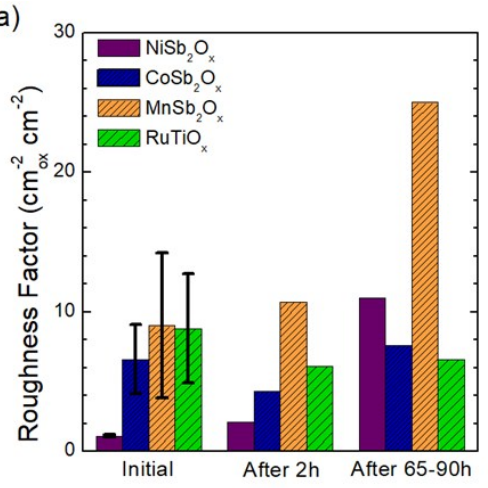

b)

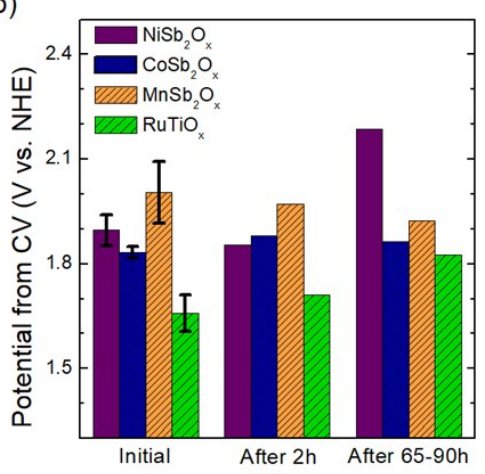

c)

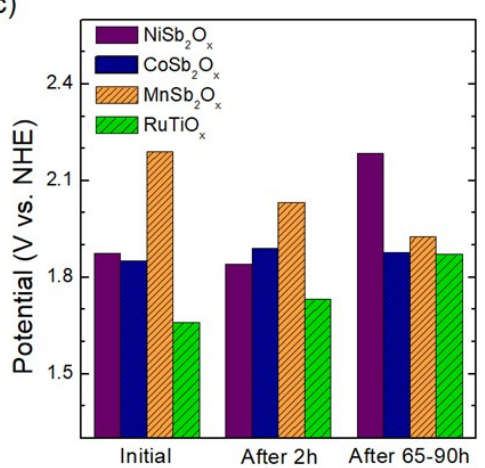

d)

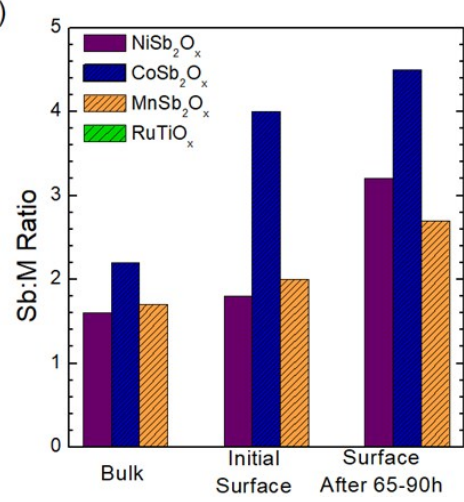

e)

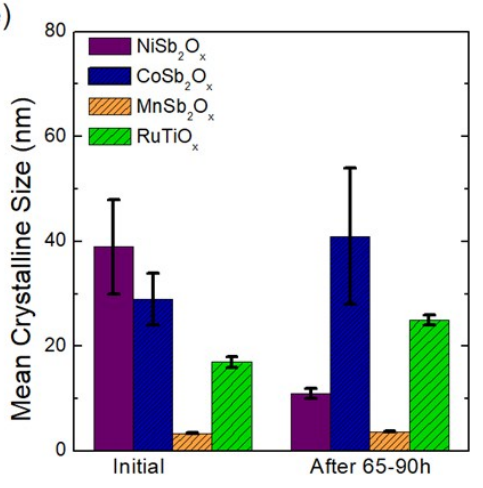

Figure S14. Summary of a) roughness factor, b) potential at $100 \mathrm{~mA} \mathrm{~cm}^{-2}$ from cyclic voltammetry, c) potential at $100 \mathrm{~mA} \mathrm{~cm}{ }^{-2}$ from chronopotentiometry, d) bulk and surface composition, and e) mean crystalline size for $\mathrm{NiSb}_{2} \mathrm{O}_{\mathrm{x}}, \mathrm{CoSb}_{2} \mathrm{O}_{\mathrm{x}}, \mathrm{MnSb}_{2} \mathrm{O}_{\mathrm{x}}$, and $\mathrm{RuTiO}_{\mathrm{x}}$. Final data is at $90 \mathrm{~h}$ for $\mathrm{CoSb}_{2} \mathrm{O}_{\mathrm{x}}, \mathrm{MnSb}_{2} \mathrm{O}_{\mathrm{x}}$, and $\mathrm{RuTiO}_{\mathrm{x}}$, and at $65 \mathrm{~h}$ for $\mathrm{NiSb}_{2} \mathrm{O}_{\mathrm{x}}$.

Table S1. Catalyst loading of $\mathrm{MSb}_{2} \mathrm{O}_{\mathrm{x}}(\mathrm{M}=\mathrm{Ni}, \mathrm{Co}$, or $\mathrm{Mn})$ films determined from ICP-MS measurements of $\mathrm{MSb}_{2}$ films dissolved in $1.0 \mathrm{M} \mathrm{H}_{2} \mathrm{SO}_{4}(\mathrm{aq})$.

\begin{tabular}{ccc} 
Catalyst & $\begin{array}{c}\text { M Loading } \\
\left.(\mathrm{nmol} \mathrm{cm})^{-2}\right)\end{array}$ & $\begin{array}{c}\text { Sb Loading } \\
(\mathrm{nmol} \mathrm{cm}\end{array}$ \\
\hline $\mathrm{NiSb}_{2} \mathrm{O}_{\mathrm{x}}$ & $483 \pm 3$ & $763 \pm 5$ \\
$\mathrm{CoSb}_{2} \mathrm{O}_{\mathrm{x}}$ & $375 \pm 4$ & $820 \pm 5$ \\
$\mathrm{MnSb}_{2} \mathrm{O}_{\mathrm{x}}$ & $417 \pm 9$ & $709 \pm 8$ \\
\hline
\end{tabular}


Table S2. Potentials vs. NHE of $\mathrm{MSb}_{2} \mathrm{O}_{\mathrm{x}}$ films and $\mathrm{RuTiO}_{\mathrm{x}}$ determined from cyclic voltammetry data prior to galvanostatic operation at geometric current densities of $100 \mathrm{~mA} \mathrm{~cm}^{-2} \mathrm{in} \mathrm{pH}=2.0$, 4.0 $\mathrm{M} \mathrm{NaCl}(\mathrm{aq})$. Roughness factors (RF) were determined from impedance data at $1.660 \mathrm{~V}$ vs. NHE. Faradaic efficiency (FE) towards the chlorine evolution reaction at a geometric current density of $100 \mathrm{~mA} \mathrm{~cm}^{-2}$ determined by iodometric titration. The faradaic efficiency experimental details such as the electrode areas, charge passed, amounts of $\mathrm{Cl}_{2}$ expected, and amount of $\mathrm{Cl}_{2}$ detected are included.

\begin{tabular}{cccccccc} 
Catalyst & $\begin{array}{c}\text { Potential at } \\
100 \mathrm{~mA} \mathrm{~cm}^{-2} \\
(\mathrm{~V})\end{array}$ & $\mathrm{RF}$ & $\begin{array}{c}\mathrm{FE} \\
\mathrm{Area} \\
\left(\mathrm{mm}^{-2}\right)\end{array}$ & $\begin{array}{c}\mathrm{FE} \\
\text { Charge } \\
\text { Passed } \\
(\mathrm{C})\end{array}$ & $\begin{array}{c}\mathrm{FE} \\
\mathrm{Cl}_{2} \\
\text { Expected } \\
(\mu \mathrm{mol})\end{array}$ & $\begin{array}{c}\mathrm{FE} \\
\mathrm{Cl}_{2} \\
\text { Detected } \\
(\mu \mathrm{mol})\end{array}$ & $\begin{array}{c}\mathrm{FE} \\
(\%)\end{array}$ \\
\hline $\mathrm{NiSb}_{2} \mathrm{O}_{\mathrm{x}}$ & $1.896 \pm 0.045$ & $1.1 \pm 0.1$ & 1.91 & 1.14 & 5.93 & $\begin{array}{c}5.43,5.83, \\
5.80\end{array}$ & $96.0 \pm 3.7$ \\
$\mathrm{CoSb}_{2} \mathrm{O}_{\mathrm{x}}$ & $1.833 \pm 0.016$ & $6.6 \pm 2.5$ & 3.49 & 2.09 & 10.8 & $\begin{array}{c}10.3,10.9, \\
10.5\end{array}$ & $97.4 \pm 3.0$ \\
$\mathrm{MnSb}_{2} \mathrm{O}_{\mathrm{x}}$ & $2.005 \pm 0.088$ & $9.0 \pm 5.2$ & 1.97 & 1.18 & 6.10 & $\begin{array}{c}5.46,5.47, \\
5.55\end{array}$ & $89.9 \pm 0.8$ \\
$\mathrm{RuTiO}_{\mathrm{x}}$ & $1.659 \pm 0.053$ & $8.8 \pm 3.9$ & 11.76 & 7.05 & 36.5 & $\begin{array}{c}35.0,34.6, \\
34.3\end{array}$ & $94.8 \pm 0.9$ \\
\hline
\end{tabular}

Table S3. Intrinsic Potential $\left(E_{\mathrm{i}}\right)$ vs. NHE at $1.0 \mathrm{~mA} \mathrm{~cm}^{-2}$ of ECSA and Tafel slope $(b)$ of $\mathrm{MSb}_{2} \mathrm{O}_{\mathrm{x}}$ films and $\mathrm{RuTiO}_{\mathrm{x}}$ prior to and after $50 \mathrm{~h}$ of galvanostatic operation at $100 \mathrm{~mA} \mathrm{~cm}{ }^{-2}$. The Tafel slope was determined from a linear fit of a plot of $\eta$ vs. $\log _{10}(J)$ between geometric current densities of 0.2 to $2.0 \mathrm{~mA} \mathrm{~cm}^{-2}$. All Tafel slopes had an R-squared value greater than 0.99 .

\begin{tabular}{ccccc} 
Catalyst & $\begin{array}{c}E_{\mathrm{i}} \text { at } 0 \mathrm{~h} \\
(\mathrm{~V})\end{array}$ & $\begin{array}{c}E_{\mathrm{i}} \text { at } 50 \mathrm{~h} \\
(\mathrm{~V})\end{array}$ & $\begin{array}{c}b \text { at } 0 \mathrm{~h} \\
(\mathrm{mV} \mathrm{dec}-1)\end{array}$ & $\begin{array}{c}b \text { at } 50 \mathrm{~h} \\
\left(\mathrm{mV} \mathrm{dec}^{-1}\right)\end{array}$ \\
\hline $\mathrm{NiSb}_{2} \mathrm{O}_{\mathrm{x}}$ & $1.602 \pm 0.018$ & 1.911 & 94 & 131 \\
$\mathrm{CoSb}_{2} \mathrm{O}_{\mathrm{x}}$ & $1.652 \pm 0.006$ & 1.705 & 73 & 74 \\
$\mathrm{MnSb}_{2} \mathrm{O}_{\mathrm{x}}$ & $1.699 \pm 0.036$ & 1.789 & 110 & 110 \\
$\mathrm{RuTiO}_{\mathrm{x}}$ & $1.460 \pm 0.010$ & 1.563 & 69 & 134 \\
\hline
\end{tabular}


Table S4. Summary of XPS binding energies observed for $\mathrm{MSb}_{2} \mathrm{O}_{\mathrm{x}}$ samples before and after electrochemical operation and literature values for various $\mathrm{M}$ and $\mathrm{Sb}$ compounds.

\begin{tabular}{cccc} 
Material & $\begin{array}{c}\mathrm{M} 2 \mathrm{p}_{3 / 2} \text { Binding Energy } \\
(\mathrm{eV})\end{array}$ & $\begin{array}{c}\mathrm{Sb} 3 \mathrm{~d}_{5 / 2} \text { Binding Energy } \\
(\mathrm{eV})\end{array}$ & Reference \\
\hline $\mathrm{NiSb}_{2} \mathrm{O}_{\mathrm{x}}$ (before) & $856.1 \pm 0.1$ & $540.4 \pm 0.1$ & - \\
$\mathrm{NiSb}_{2} \mathrm{O}_{\mathrm{x}}$ (after) & $856.3 \pm 0.1$ & $540.5 \pm 0.1$ & - \\
$\mathrm{CoSb}_{2} \mathrm{O}_{\mathrm{x}}$ (before) & $781.2 \pm 0.1$ & $540.6 \pm 0.1$ & - \\
$\mathrm{CoSb}_{2} \mathrm{O}_{\mathrm{x}}$ (after) & $781.2 \pm 0.1$ & $540.3 \pm 0.1$ & - \\
$\mathrm{MnSb}_{2} \mathrm{O}_{\mathrm{x}}$ (before) & $641.9 \pm 0.1$ & $540.2 \pm 0.1$ & - \\
$\mathrm{MnSb}_{2} \mathrm{O}_{\mathrm{x}}$ (after) & $642.0 \pm 0.1$ & $540.3 \pm 0.1$ & - \\
$\mathrm{NiCl}$ & 856.77 & - & 15 \\
$\mathrm{Ni}_{2}(\mathrm{OH})_{2}$ & 855.80 & - & 15 \\
$\mathrm{CoCl}_{2} \bullet\left(\mathrm{H}_{2} \mathrm{O}\right)_{6}$ & 782.1 & - & 16 \\
$\mathrm{Co}_{2}(\mathrm{OH})_{2}$ & 780.65 & - & 6 \\
$\mathrm{MnCl}_{2}$ & 642.0 & - & 17 \\
$\mathrm{Sb}_{2} \mathrm{O}_{3}$ & - & 539.7 & 8 \\
$\mathrm{Sb}_{2} \mathrm{O}_{4}$ & - & 540.3 & 8 \\
$\mathrm{Sb}_{2} \mathrm{O}_{5}$ & - & 540.6 & 8 \\
\hline
\end{tabular}

Table S5. Example of impedance data collected and ECSA determined for $\mathrm{MSb}_{2} \mathrm{O}_{\mathrm{x}}$ and $\mathrm{RuTiO}_{\mathrm{x}}$ films.

\begin{tabular}{ccccccccc} 
Catalyst & $\begin{array}{c}\text { Area } \\
\left(\mathrm{cm}^{-2}\right)\end{array}$ & $\begin{array}{c}R_{S} \\
(\Omega)\end{array}$ & $\begin{array}{c}Q_{0} \\
\mu \mathrm{F} \mathrm{s}\end{array}$ & $a$ & $\begin{array}{c}R_{c t} \\
(\mathrm{a}-1)\end{array}$ & $\begin{array}{c}C_{D L} \\
(\mu \mathrm{F})\end{array}$ & $\begin{array}{c}\text { ECSA } \\
\left(\mathrm{cm}^{-2}\right)\end{array}$ & $\mathrm{RF}$ \\
\hline $\mathrm{NiSb}_{2} \mathrm{O}_{\mathrm{x}}$ & 0.0179 & 110.2 & 6.87 & 0.714 & 343.3 & 0.341 & 0.0316 & 1.76 \\
$\mathrm{CoSb}_{2} \mathrm{O}_{\mathrm{x}}$ & 0.0282 & 29.29 & 2.87 & 0.912 & 396.6 & 1.15 & 0.1049 & 3.72 \\
$\mathrm{MnSb}_{2} \mathrm{O}_{\mathrm{x}}$ & 0.0179 & 153.1 & 21.0 & 0.704 & 1,522 & 1.81 & 0.1645 & 9.19 \\
$\mathrm{RuTiO}_{\mathrm{x}}$ & 0.2030 & 16.91 & 49.9 & 0.871 & 8.790 & 14.9 & 1.355 & 6.67 \\
\hline
\end{tabular}




\section{References}

1. H. Bisht, H.-T. Eun, A. Mehrtens and M. A. Aegerter, Thin Solid Films, 1999, 351, 109114.

2. I. A. Moreno-Hernandez, C. A. MacFarland, C. G. Read, K. M. Papadantonakis, B. S. Brunschwig and N. S. Lewis, Energy Environ. Sci., 2017, 10, 2103-2108.

3. N. Menzel, E. Ortel, K. Mette, R. Kraehnert and P. Strasser, ACS Catal., 2013, 3, 13241333.

4. S. Grazulis, D. Chateigner, R. T. Downs, A. F. Yokochi, M. Quiros, L. Lutterotti, E. Manakova, J. Butkus, P. Moeck and A. Le Bail, J. Appl. Crystallogr., 2009, 42, 726-729.

5. J. D. Donaldson, A. Kjekshus, D. G. Nicholson and T. Rakke, Acta Chem. Scand. A, 1975, 29, 803-809.

6. M. C. Biesinger, B. P. Payne, A. P. Grosvenor, L. W. M. Lau, A. R. Gerson and R. S. C. Smart, Appl. Surf. Sci., 2011, 257, 2717-2730.

7. M. C. Biesinger, B. P. Payne, L. W. M. Lau, A. Gerson and R. S. C. Smart, Surf. Interface Anal., 2009, 41, 324-332.

8. R. Izquierdo, E. Sacher and A. Yelon, Appl. Surf. Sci., 1989, 40, 175-177.

9. J. I. Partanen and A. K. Covington, J. Chem. Eng. Data, 2009, 54, 208-219.

10. C. C. McCrory, S. Jung, J. C. Peters and T. F. Jaramillo, J. Am. Chem. Soc., 2013, 135, 16977-16987.

11. M. Wohlfhart-Mehrens and J. Heitbaum, J. Electroanal. Chem., 1987, 237, 251-260.

12. in Standard Methods For the Examination of Water and Wastewater, DOI: 10.2105/smww.2882.078.

13. C. E. Finke, S. T. Omelchenko, J. T. Jasper, M. F. Lichterman, C. G. Read, N. S. Lewis and M. R. Hoffmann, Energy Environ. Sci., 2019, 12, 358-365.

14. M. Jiang, H. Wang, Y. Li, H. Zhang, G. Zhang, Z. Lu, X. Sun and L. Jiang, Small, 2017, 13.

15. M. C. Biesinger, L. W. Lau, A. R. Gerson and R. S. Smart, Phys. Chem. Chem. Phys, 2012, 14, 2434-2442.

16. D. G. Brown and U. Weser, Z. Naturforsch. (B), 1979, 34, 1468-1470.

17. A. Aoki, Jpn. J. Appl. Phys, 1976, 15, 305-311. 